\title{
Building Academic Communities to Support Nursing Students with Disabilities: An Integrative Review
}

\author{
Leslie Neal-Boylan, PhD, APRN, CRRN, FAAN \\ MGH Institute of Health Professions \\ Michelle Miller, JD, MPH, RN \\ Quinnipiac University \\ Jessica Bell, MS \\ MGH Institute of Health Professions
}

\begin{abstract}
Background: Students with disabilities in higher education are increasing, yet discrimination against nurses and nursing students with disabilities persists. A healthy academic community must include students with disabilities who are receiving accommodations per the ADAAA.

Aim: To determine the extent, if any, of progress in accommodating nursing students with disabilities since the enactment of the Americans with Disabilities Act Amendment (ADAAA) of 2008.

Methods: An integrative review of peer-reviewed literature written in English was conducted. The Cumulative Index to Nursing \& Allied Health Literature (CINAHL), PubMed, and Educational Resources Information Center (ERIC) were searched. The date range spanned from 2008 to 2018. The type of peerreviewed literature was not specified.

Results: Accommodating students with disabilities depends on individual faculty who remain concerned about patient safety. Faculty tend to view students with disabilities using a medical rather than a social model and evaluate students on the ability to perform essential functions of the job instead of on student competencies.

Conclusions: Faculty are more aware of the needs of nursing students with disabilities and the need to accommodate them, yet discrimination still occurs. Academic communities must not discriminate against students with disabilities and should structure an interdisciplinary approach that includes assistance from the university disability office, education of faculty about the ADAAA and the development of sustainable educational models that integrate the individualized needs of all learners.
\end{abstract}

Submitted 23 March 2018: accepted 23 April 2018

Keywords: nurses with disabilities, students with disabilities, nursing students

The Americans with Disabilities Act of 1990 (ADA) as amended by the Americans with Disabilities Amendments Act of 2008 (ADAAA; 2008) contains legal mandates obligating universities and colleges to provide reasonable accommodations to students with disabilities. The health of any academic community can be partially measured by not only the inclusion of students with disabilities, but also by the level of its commitment to providing the reasonable accommodations necessary to create equal opportunities for these students to succeed. Students with disabilities in 
higher education are increasing (L'Ecuyer, 2014; Symes, 2014). A healthy academic community must include students with disabilities who are receiving accommodations per the federal statute.

In 2016, approximately 12.8 percent of non-institutionalized people of all ages living in the United States reported having a disability. In that year, approximately $19 \%$ of people with a high school diploma or its equivalent reported a disability (Erickson, Lee, \& Von Schrader, 2017). In 2011-2012, 11\% of undergraduates in postsecondary schools reported having a disability. That number had not changed since the 2007-2008 report (United States Department of Education, 2016).

Extensive research has been conducted on the work life experiences and perceptions of nurses with disabilities. Nurses with disabilities worry that they will jeopardize patient safety (Neal-Boylan, 2012; 2014; Neal-Boylan, Hopkins, Skeete, et al., 2012). Nurse educators have this same concern about students with disabilities (Aaberg, 2012; Ashcroft \& Lutfiyya, 2013). Nurse educators are more likely than the general population to be negatively biased toward students with visible disabilities (Aaberg, 2012). Nursing students with learning disabilities are more likely to earn admission into nursing school than are nursing students with physical disabilities (Betz, Smith \& Bui, 2012). This may be because nurse educators tend to emphasize hands-on care (Aaberg, 2012).

Nursing students as well as nursing faculty, may have negative biases of peers and other people with disabilities which may add to unwelcome and consequently unhealthy environments for people with disabilities who'd like to attend nursing school (Shpigelman, Zlotnick, \& Brand, 2016). In Canada, a study involving nurse educators revealed that faculty perceived that nursing students with disabilities can become effective nurses and should be admitted to nursing schools but that reluctance to disclose the disability and other factors pertaining to educating students with disabilities were challenging. Individual nurse educator and student attributes, as well as the environment were significant factors in the views of the study participants (Ashcroft \& Lutfiyya, 2013).

Schools of nursing often have difficulty differentiating technical standards from essential functions. Nonacademic requirements for admission are technical functions; essential functions are the abilities a nurse needs in the employment setting (Levey, 2014; Matt, Maheady, \& Fleming, 2015). Technical standards should not dictate how the skill should be performed (Matt, et. al., 2015) or be the criteria for completion of a program (Evans, 2014a, 2015).

Academic communities vary regarding whether they have a separate office of disability services or one person designated to assist students with disabilities with accommodation requests and assessments. Despite the ADA and the ADAAA, faculty management of cases involving students with disabilities also varies. Research studies focused on nurses with disabilities indicate that many nurses perceive discrimination in the workplace (Neal-Boylan, 2012; Neal-Boylan, 2014). However, some nurses have been able to find employment despite their disabilities (Neal-Boylan, 2014; Neal-Boylan \& Miller, 2017). Among these are nurses who had disabilities while in school (Neal-Boylan \& Miller, 2017). Despite the success stories and a lack of documentation of any connection between injury to a patient and a nurse's disability, the prevailing notion persists that nurses must be able- bodied. Consequently, nursing students are rarely admitted if they have a visible and/or significant disability.

Schools of nursing have made a concerted effort to increase inclusion and diversity among their students and faculty. Professional nursing organizations, such as the American Nurses Association (1998), National League for Nursing (2016) and American Association of Colleges of Nursing (Rosseter, 2018) have declared their positions on discrimination based on disability, a fact which does not seem to have resulted in increased acceptance of disabled nursing students. This integrative review sought to identify whether academic environments have changed for prospective and current nursing students with disabilities since the enactment of the ADAAA. This review has 
implications for students with disabilities, in general and is significant because the number of students with disabilities in higher education is increasing.

\section{METHOD}

With the assistance of a librarian (Bell), a preliminary search of English language literature was undertaken to determine the appropriate strategy for reviewing the literature to respond to the research question. The integrative review method (Russell, 2005) was chosen based on the results. The authors conducted a keyword and subject heading search of the literature (Table 1) as of March 2018 using CINAHL, PubMed, and ERIC databases. The selected population for the review was nursing students, prospective or current. The review process proceeded from a search of the literature to an evaluation of the articles therein to analysis and synthesis of the results. The inclusion criteria were: (1) Available in English, (2) focused on nursing students, prospective or current with any type of disability, (3) peer-reviewed, (4) from the date range of 2008 (the enactment of the ADAAA) to March 2018; and (5) limited to countries which have enacted legislation requiring reasonable accommodations be afforded by institutions of higher learning to disabled students. Articles with a focus on teaching students to care for people with disabilities or that measured the attitudes of nursing students toward people with disabilities were excluded from the review.

Table 1

Search Terms and Citation Counts by Database

\begin{tabular}{|c|c|c|c|c|}
\hline Database & Date & Search Terms & Limits & $\begin{array}{l}\text { Citations } \\
\text { retrieved }\end{array}$ \\
\hline CINAHL & $3 / 16 / 18$ & $\begin{array}{l}\text { Subject Headings: } \\
\text { "education, } \\
\text { nursing," } \\
\text { "students, } \\
\text { nursing," } \\
\text { "students, } \\
\text { disabled" } \\
\text { Keywords: } \\
\text { nursing students, } \\
\text { students with } \\
\text { disabilities, } \\
\text { disabled students }\end{array}$ & $\begin{array}{l}\text { Date: 2008-2018 } \\
\text { English Language }\end{array}$ & 73 \\
\hline PubMed & $3 / 16 / 18$ & $\begin{array}{l}\text { MeSH: } \\
\text { "education, } \\
\text { nursing," } \\
\text { "students, } \\
\text { nursing," }\end{array}$ & $\begin{array}{l}\text { Date: } 2008-2018 \\
\text { English language }\end{array}$ & 88 \\
\hline
\end{tabular}




\begin{tabular}{|c|c|c|c|c|}
\hline & & $\begin{array}{l}\text { "disabled } \\
\text { persons" } \\
\text { Keyword: nursing } \\
\text { students, students } \\
\text { with disabilities, } \\
\text { disabled students }\end{array}$ & & \\
\hline \multirow[t]{2}{*}{ ERIC } & $3 / 16 / 18$ & $\begin{array}{l}\text { Subject Headings: } \\
\text { "nursing } \\
\text { education," } \\
\text { "special needs } \\
\text { students" } \\
\text { Keywords: } \\
\text { "nursing } \\
\text { students," } \\
\text { "students with } \\
\text { disabilities," } \\
\text { "disabled } \\
\text { students", }\end{array}$ & Date: $2008-2018$ & 9 \\
\hline & & & & $\begin{array}{l}170 \\
\text { duplicates } \\
\text { removed })\end{array}$ \\
\hline
\end{tabular}

\section{RESULTS}

A total of 170 articles met the inclusion criteria and were reviewed. Two authors reviewed the content of the literature and separately developed their own interpretations. They then discussed the interpretations and reached consensus. Most of the articles were published in the United States. Other countries included the United Kingdom, Ireland, Canada, Israel and Australia. 
Table 2

Summary of Peer-Reviewed Literature

\begin{tabular}{|l|l|l|}
\hline Author & Year & Content \\
\hline Aaberg & 2012 & $\begin{array}{l}\text { Students with visible } \\
\text { disabilities are under- } \\
\text { represented in nursing }\end{array}$ \\
\hline Ailey, et al. & 2016 & A commitment to diversity \\
\hline Ashcroft, et al. & 2008 & $\begin{array}{l}\text { Accommodations cause } \\
\text { concern for faculty }\end{array}$ \\
\hline Ashcroft & 2012 & $\begin{array}{l}\text { Perspective is influenced by } \\
\text { context }\end{array}$ \\
\hline Azzopardi, et al. & 2014 & $\begin{array}{l}\text { Simulation assists with } \\
\text { assessment of } \\
\text { accommodations }\end{array}$ \\
\hline Carey & 2012 & Concerns about patient safety \\
\hline Davidson, et al. & 2016 & Barriers to inclusion still exist \\
\hline Evans & $2014 \mathrm{~b}, \mathrm{c}, 2015$ & $\begin{array}{l}\text { Decision to disclose is } \\
\text { multifaceted }\end{array}$ \\
\hline Heelan, et al. & 2015 & Universal design is preferable \\
\hline Rankin, et al. & 2010 & $\begin{array}{l}\text { Collaboration is necessary } \\
\text { mocial model vs. medical }\end{array}$ \\
\hline Marks \& McCullough & 2016 & $\begin{array}{l}\text { Essential functions are a } \\
\text { barrier }\end{array}$ \\
\hline Matt, et al. & 2015 & $\begin{array}{l}\text { Faculty don't understand the } \\
\text { ADA }\end{array}$ \\
\hline May & 2014 & No “one size fits all" \\
\hline $\begin{array}{l}\text { Neal-Boylan \& Smith } \\
\text { Neal-Boylan \& Miller }\end{array}$ & 2016 & \\
\hline
\end{tabular}

\section{Identifying the Problem}

The literature dated 2008 identified faculty attitudes toward nursing students with disabilities (Goins, 2008) including the possibility that faculty may be penalizing students for having disabilities or being ill (Gibson, 2008). These articles conclude that students with disabilities have the right to equitable access across academic communities (Sharples, 2008) and that faculty must work to develop a framework for working with these students and providing accommodations. However, special consideration should be given to how these students will perform in the clinical setting (Ashcroft, Chernomas, Davis, et al., 2008).

In Great Britain, Sin and Fong (2008) found that imprecise legal language pertaining to the fitness requirements of nurses led to misinterpretation of what should be required of nursing students and were inclined to foster 
discrimination. Ferguson, et al. (2009) encouraged faculty to assist nursing students with disabilities and called them an "untapped resource." Research identified discriminatory practices in the admission of nursing students with disabilities (Aaberg, 2010). Dahl (2010) found that faculty were using a medical model to assess the capabilities of nursing students with disabilities and were unaware of their own discriminatory practices. The authors recommended that faculty change their beliefs and ways of thinking to avoid treating these students unfairly. Interestingly, Fowell (2010) called students with disabilities "damaged" and advised faculty not to exclude them.

\section{Collaboration is Best}

By 2010, the need for an interdisciplinary approach to include the university disability office was acknowledged (Tee et al., 2010) In addition, consultation with faculty and clinical placement coordinators was considered a better approach then working with students without these support systems (Griffiths, Worth, Scullard, \& Gilbert, 2010). The need for collaborative services was echoed by Hoepner and Maheady (2010) with the addition of peer support, perseverance and wellness programs. Authors began to realize that the tools commonly used to educate nursing students might need adaptation for nursing students with disabilities (Marcyjanik, \& Zorn, 2011). Researchers in Australia sought to understand how their anti-discrimination legislation was impacting nursing students in clinical practice settings and concluded that collaboration between educators and clinical staff was key. Being proactive was found to be effective as was the importance of recognizing the student's right to disclose or keep the disability confidential (Rankin, Nayda, Cocks, et. al, 2010).

\section{Meeting Individual Student Needs}

One study found that students with dyslexia felt the necessity to disclose their disability because they did not want to jeopardize patient safety, although they felt fully capable of performing their duties and recognized their responsibilities. Disclosing the disability caused anxiety; however, the researchers concluded that early identification of the diagnosis could help educators provide individual support for these students (Ridley, 2011). Later, Pace (2016) found that students with dyslexia and other learning disabilities could use strategies, such as double checking with mentors or preceptors, to be effective in the clinical setting. Ryan (2011) reiterated that negative attitudes toward nursing students with disabilities regarding their work in the clinical setting came from a lack of understanding and awareness of requirements of the law and their institution.

\section{Lack of Awareness and Education by Nurse Faculty}

By 2012, researchers were continuing to find that although faculty expressed positive attitudes toward nursing students with disabilities, prospective students who could not hide their disabilities were being discriminated against and denied admission (Aaberg, 2012). Perceptions regarding the environment, the student and the nursing program influenced the perceptions of nurse educators about students with disabilities. The question of balancing the rights of students against concerns about patient safety continued to surface in the literature (Ashcroft, 2012).

Faculty began to struggle with the increasing emphasis on inclusivity. Because of a lack of understanding and awareness among nurse educators, responses to students with disabilities were likely to be open to faculty interpretation (Carey, 2012). Misinformation and misunderstanding regarding the legal requirements of the ADA as amended by the ADAAA had led to inadvertent and unintended discrimination. Correcting this could enable students 
of varying disabilities to successfully complete nursing programs (Dupler, Allen, Maheady, Fleming, \& Allen, 2012; May, 2013; May, 2014).

Researchers continued to find significantly fewer students with physical disabilities than those with learning disabilities in nursing school. Accommodations when sought by students, typically included increased testing times and mostly involved classroom work rather than clinical work (Betz, Smith, \& Bui, 2012). Student stories were valuable in helping faculty and preceptors increase their awareness and understanding of the needs of students with disabilities (Tee \& Cowen, 2012). Adaptations to support deaf and other nursing students with disabilities were identified and supported the need for increased awareness among nursing faculty of the types of accommodations that would support student success (Sharples, 2013; Meloy \& Gambescia, 2014). One study of nursing students with dyslexia in Ireland revealed that students with dyslexia had more difficulty than non-dyslexic students with both writing and reading patient notes and working with care plans (Sanderson-Mann, Wharrad, \& McCandless, 2012).

\section{A Multipronged Approach}

Researchers who studied accommodations used in clinical practice by students with disabilities found that counseling, mentoring and consultation with people in the office of disability were the most frequently used strategies and assisted students to disclose their concerns. Constructive suggestions and recommendations from clinical instructors and preceptors also assisted students (Symes, 2014). Students echoed this reasoning stating that the decision to disclose was dependent on the environment and whether there was good communication and support from clinical faculty (Howlin, Halligan, \& O'Toole, 2014a). These researchers developed a tool to help students identify their needs for accommodation in the clinical setting (Howlin, Halligan, \& O'Toole, 2014b).

Students with dyslexia were concerned about appearing dumb if they disclosed their disability in the clinical setting (Evans, 2014b) but disclosure is often necessary to provide reasonable and appropriate accommodations (Evans, 2015). While nurse educators expressed concerns about patient safety they did not perceive significant barriers to accommodations for students (Symes, 2014). The research continued to demonstrate a correlation between faculty lack of knowledge and confidence regarding the law and how to provide reasonable accommodations, and a preconception of an association between the nurse's disability and patient injury with less willingness to provide accommodations for students. Interestingly, nurse educators and preceptors expressed positive attitudes about supporting students while expressing a lack of confidence in providing accommodations (L'Ecuyer, 2014; May, 2014). Simulation was suggested as a means by which educators could determine the appropriate accommodations needed in the clinical setting (Azzopardi et al., 2014).

\section{Implementing Accommodations}

More recently, some academic communities have made intentional efforts to create and implement accommodations to support students with disabilities (Ailey et al., 2016; Birkhead, 2018). The use of universal design was introduced as a way of configuring the environment to support all students including those with disabilities (Heelan et al., 2015). Although a lack of understanding and education among nurse educators is still pervasive, there is recognition of the need for realistic expectations, resilience and support (Davidson et al., 2016). 


\section{Not a "One Size Fits All” Approach}

Researchers compared students with and without disabilities and their perceptions of their clinical experiences. Both groups experienced difficulties but students with disabilities often perceived increased difficulties resulting from the attitudes of others (Hill \& Roger, 2016). Neal-Boylan and Smith (2016) stressed and a research study confirmed (NealBoylan \& Miller, 2017) that there is no right answer to fit all students but that each approach should be individualized. Luckowski 's (2016) study of the lived experiences of students with disabilities found similar results. In addition, students admitted to missing clinical and limiting their performance in clinical; however, the students perceived discrimination in the clinical setting and the researcher recommended faculty orientation and education.

\section{Identifying Best Practices}

Marks and McCulloh (2016) identified best practices for helping academic communities support nursing students with disabilities and encouraged faculty to turn away from a medical model, toward a social model of viewing disability. Matt, Maheady and Fleming (2015) helped differentiate technical standards from essential nursing functions. Still, employed nurses who had disabilities while in nursing school reported they had tried to hide their disabilities in school and perceived that faculty were angry and fearful, telling students they could not become nurses. These nurses had developed their own accommodations and worked hard so others would think them worthy while just wanting to be treated like everyone else (Neal-Boylan \& Miller, 2017). A white paper developed in California described the need for and practical ways of including students with disabilities and suggested an alternative and ADA compliant version of technical standards (Oermann, 2016).

\section{DISCUSSION}

The ADA as amended by the ADAAA expressly notes the right of disabled individuals to participate fully in society (42 U.S.C. sec. 12101(a)(2)). The literature reflects a steady increase in the admission of disabled students into nursing programs (L'Ecuyer, 2014; Symes, 2014; Luckowski, 2016) and building healthy academic communities to support these students provides the foundation for full academic and societal engagement. Moreover, a growing number of nurse educators express the belief that disabled students can become good nurses and the willingness to work with disabled students (Ashcroft, 2012; L'Ecuyer, 2014).

Counterbalancing these positive developments, the literature also reveals that many educators are not familiar with legal requirements to create reasonable accommodations for disabled students (May, 2014). This lack of awareness creates a situation in which the experience of disabled nursing students is highly variable depending on the individual faculty member or preceptor with whom they are dealing at any given time (Carey, 2012). Even when nurse educators are aware of the law and may express support of disabled students, there seems to exist an implicit bias against disabled students (Aaberg, 2012). It is hardly a wonder then that disabled nursing students remain exceedingly hesitant to disclose their disability, fearing stigma and ridicule (Ridley, 2011; Neal-Boylan \& Miller, 2017). Those who do disclose often report being treated differently (Sanderson-Mann et al., 2012).

Competencies related to the clinical setting constitute the most challenging aspect of the inclusion of disabled nursing students in academic communities (Howlin et al., 2014a; Salkeld, 2016). An oft-repeated theme in the literature is the fear of nurse educators that patient safety may be compromised because of the accommodations given to disabled students (Ashcroft, 2012; Sanderson-Mann et al., 2012; Symes, 2014). Many papers note in this context 
that nursing faculty and preceptors must be given clearer guidelines as to what is required by the law and how reasonable accommodations can be fashioned without endangering patient safety (Ashcroft, 2012). It is critical that schools seek an interdisciplinary approach including assistance from the university disability office (Griffiths et al., 2010; Marcyjanik \& Zorn, 2011), train faculty in the law (Dupler et al., 2012), and develop educational models that integrate individualized needs of learners (Sin, 2009; Ridley, 2011; Heelan et al., 2013; Marks \& McCulloh, 2016).

\section{CONCLUSION}

While this literature review focused on nursing education, it is logical to assume other students with disabilities may face similar barriers and other faculty may share ignorance of the law and what constitutes discrimination. This is particularly true of students in clinical settings where faculty and staff must be willing to define very specifically the competencies that must be demonstrated and how they may be achieved in non-traditional ways. It is worth reviewing the literature and conducting research regarding all health professions students with disabilities to confirm this. In this era of inclusion, it is important that academic communities welcome students (and employees) with disabilities and comply with the law regarding accommodating people with disabilities. Academic communities should make an intentional effort to increase faculty and staff awareness of the law and how they can admit and support students, staff and faculty with disabilities. A healthy academic campus is inclusive, compliant with the law and welcoming to people with disabilities. 


\section{REFERENCES}

Aaberg, V.A. (2012). A path to greater inclusivity through understanding implicit attitudes toward disability. Journal of Nursing Education, 51(9), 505-510. https://doi.org/10.3928/01484834-20120706-02

Ailey, S. H., Brown, P., Friese, T. R., \& Dugan, S. (2016). Building a culture of inclusion...disability as opportunity for organizational growth and improving patient care.Journal of Nursing Administration,46(1), 9-11. https://doi.org/10.1097/NNA.0000000000000286

American Nurses Association. (1998). Discrimination and racism in health care. Kansas City, Mo.: ANA.

Americans with Disabilities Amendments Act (ADAAA) of 2008, Pub. L. No. 110-325, 122 Stat. 3553 (2008).

Americans With Disabilities Act (ADA) of 1990, 42 U.S.C.A. \ 12101 et seq. (West 2014).

Ashcroft, T. J., Chernomas, W. M., Davis, P. L., Dean, R. A., Seguire, M., Shapiro, C. R., \& Swiderski, L. M. (2008). Nursing students with disabilities: One faculty's journey. International Journal of Nursing Education Scholarship, 5, 923X.1424. https://doi.org/10.2202/1548-923X.1424

Ashcroft, T. J. (2012). Nursing educators' perspectives of nursing students with disabilities. (109859799). Retrieved from https://umanitoba.ca/faculties/education/media/Ashcroft12.pdf

Ashcroft, T. J., \& Lutfiyya, Z.M. (2013). Nursing educators' perspectives of students with disabilities: A grounded theory study. Nursing Education Today, 33, 1316-1321. https://doi.org/10.1016/j.nedt.2013.02.018

Azzopardi, T., Johnson, A., Phillips, K., Dickson, C., Hengstberger-Sims, C., Goldsmith, M., \& Allan, T. (2014). Simulation as a learning strategy: Supporting undergraduate nursing students with disabilities. Journal of Clinical Nursing, 23(3), 402-409. https://doi.org/10.1111/jocn.12049

Betz, C. L., Smith, K.A., \& Bui, K. (2012). A survey of California nursing programs: Admission and accommodation policies for students with disabilities. Journal of Nursing Education, 51(12), 676-684. https://doi.org/10.3928/01484834-20121112-01

Birkhead, S. F. (2018). Testing off the clock: Allowing extended time for all students on tests. Journal of Nursing Education, 57(3), 166-169. https://doi.org/10.3928/01484834-20180221-08

Carey, P. (2012). Exploring variation in nurse educators' perceptions of the inclusive curriculum. International Journal of Inclusive Education, 16(7), 741-755. https://doi.org/10.1080/13603116.2010.516773

Dahl, D. L. (2010). Faculty beliefs related to admitting and educating nursing students with disabilities. (109853350). Retrieved from https://conservancy.umn.edu/bitstream/handle/11299/90744/Dahl_umn_0130E_11006.pdf?sequen $\mathrm{ce}=1$

Davidson, P. M., Rushton, C. H., Dotzenrod, J., Godack, C. A., Baker, D., \& Nolan, M. N. (2016). Just and realistic expectations for persons with disabilities practicing nursing. American Medical Association Journal of Ethics, 18(10), 1034-1040. https://doi.org/10.1001/journalofethics.2016.18.10.msoc1-1610

Dupler, A. E., Allen, C., Maheady, D. C., Fleming, S. E., \& Allen, M. (2012). Leveling the playing field for nursing students with disabilities: Implications of the amendments to the Americans with disabilities act. The Journal of Nursing Education, 51(3), 140-144. https://doi.org/10.3928/01484834-20120127-05 
Erickson, W., Lee, C., von Schrader, S. (2017). Disability Statistics from the American Community Survey (ACS). Ithaca, NY: Cornell University Yang-Tan Institute (YTI). Retrieved from Cornell University Disability Statistics website: www.disabilitystatistics.org

Evans, W. (2014c). If they can't tell the difference between duphalac and digoxin you've got patient safety issues. nurse lecturers' constructions of students' dyslexic identities in nurse education. Nurse Education Today, 34(6), 41. https://doi.org/10.1016/j.nedt.2013.11.004

Evans, B. (2014a). Health care professionals with disabilities career trends, best practices and call-to-action policy roundtable. March 18, 2014, U. S. Access Board. Washington DC: Event Proceedings.

Evans, W. (2014b). 'I am not a dyslexic person I'm a person with dyslexia': Identity constructions of dyslexia among students in nurse education. Journal of Advanced Nursing, 70(2), 360-372. https://doi.org/10.1111/jan.12199

Evans, W. (2015). Disclosing a dyslexic identity. British Journal of Nursing, 24(7), $383-385$. https://doi.org/10.12968/bjon.2015.24.7.383

Ferguson, D. S., Evans, V. S., Hajduk, D. B., Jones, D. L., Liston, D., Myers, E., . . Zuraikat, N. (2009). Enable the disabled: An untapped resource for the nursing shortage. Nursing Management, 40(2), 9-11. https://doi.org/10.1097/01.NUMA.0000345866.84071.b3

Fowell, M. (2010). 'Damaged' nurses require support and not exclusion [Letter]. Nursing Standard, $25(8), 32$. https://doi.org/10.7748/ns.25.8.32.s40

Gibson, M. (2008). Students should not be penalised by ill-health [Letter]. Nursing Times, 104(15), 14. Retrieved from https://www.nursingtimes.net/

Goins, L. W. (2008). Nursing faculty attitudes toward inclusion of students with disabilities to nursing education programs [Poster abstract]. Southern Online Journal of Nursing Research, 8(2). Retrieved from https://www.snrs.org

Griffiths, L., Worth, P., Scullard, Z., \& Gilbert, D. (2010). Supporting disabled students in practice: A tripartite approach. Nurse Education in Practice, 10(3), 132-137. https://doi.org/10.1016/j.nepr.2009.05.001

Heelan, A., Halligan, P., \& Quirke, M. (2015). Universal design for learning and its application to clinical placements in health science courses (practice brief). Journal of Postsecondary Education and Disability, 28(4), 469-479. Retrieved from https://files.eric.ed.gov/fulltext/EJ1093589.pdf

Hill, S., \& Roger, A. (2016). The experience of disabled and non-disabled students on professional practice placements in the United Kingdom. Disability \& Society, 31(9), 1205-1225. https://doi.org/10.1080/09687599.2016.1236718

Hoepner, C. T., \& Maheady, D. (2010). Degrees of success. success strategies for nursing students with mental illness. Minority Nurse, 36-39. Retrieved from https://minoritynurse.com

Howlin, F., Halligan, P., \& O'Toole, S. (2014a). Development and implementation of a clinical needs assessment to support nursing and midwifery students with a disability in clinical practice: Part 1. Nurse Education in Practice, 14(5), 557-564. https://doi.org/10.1016/j.nepr.2014.07.003 
Howlin, F., Halligan, P., \& O'Toole, S. (2014b). Evaluation of a clinical needs assessment and exploration of the associated supports for students with a disability in clinical practice: Part 2. Nurse Education in Practice, 14(5), 565-572. https://doi.org/10.1016/j.nepr.2014.06.009

Levey, J.A. (2014). Attitudes of nursing faculty towards nursing students with disabilities: An integrative review. Journal of Postsecondary Education and Disability, 27(3): 321-332. Retrieved from https:// files.eric.ed.gov/fulltext/EJ1048784.pdf

L'Ecuyer, K. M. (2014). Attitudes of staff nurse preceptors related to the education of nurses with learning disabilities in clinical settings. (109763316). Retrieved from https://search.proquest.com

Luckowski, A. (2016). The lived experience in the clinical setting of nursing students with disabilities. Nursing Education Perspectives (Wolters Kluwer Health), 37(5), 256-261.

Marcyjanik, D., \& Zom, C. R. (2011). Accessibility in online nursing education for persons with disability. Nurse Educator, 36(6), 241-245. https://doi.org/10.1097/NNE.0b013e3182333f9d

Marks, B., \& McCulloh, K. (2016). Success for students and nurses with disabilities. Nurse Educator, 41(1), 9-12. https://doi.org/10.1097/NNE.0000000000000212

Matt, S.B., Maheady, D., \& Fleming, S.E. (2015). Educating nursing students with disabilities: Replacing essential functions with technical standards for program entry criteria. Journal of Postsecondary Education and Disability, 28(4), 461-468. Retrieved from https:/ / files.eric.ed.gov/fulltext/EJ1093588.pdf

May, K. G. (2013). Assessing faculty knowledge of disability-related law and providing academic accommodation. (109865463). Retrieved from https://library.villanova.edu

May, K. A. (2014). Nursing faculty knowledge of the Americans with disabilities act. Nurse Educator, 39(5), $241-245$. https://doi.org/10.1097/NNE.0000000000000058

Meloy, F., \& Gambescia, S. F. (2014). Guidelines for response to student requests for academic considerations: Support versus enabling. Nurse Educator, 39(3), 138-142. https://doi.org/10.1097/NNE.0000000000000037

National League for Nursing. (2016). Achieving diversity and meaningful inclusion in nursing education. Washington DC: National League for Nursing.

Neal-Boylan, L. (2014). Nurses with Disabilities: Their job descriptions and work expectations. Rehabilitation Nursing, 39(4), 169-177. https://doi.org/10.1002/rnj.122

Neal-Boylan, L.J. (2012). An exploration and comparison of the worklife experiences of registered nurses and physicians with permanent physical and/or sensory disabilities. Rebabilitation Nursing, 37(1), 3-10. https://doi.org/10.1002/RNJ.00005

Neal-Boylan, L., Hopkins, A., Skeete, R., Hartmann, S. B., Iezzoni, L.I., Nunez-Smith, M. (2012). The career trajectories of health care professionals practicing with permanent disabilities. Academic Medicine, 87(2), 172-178. https://doi.org/10.1097/ACM.0b013e31823e1e1c

Neal-Boylan, L., \& Miller, M. (2017). Treat me like everyone else. Nurse Educator, 42(4), 176-180. https://doi.org/10.1097/NNE.0000000000000348 
Neal-Boylan, L., \& Smith, D. (2016). Nursing students with physical disabilities. Nurse Educator, 41(1), 13-18. https://doi.org/10.1097/NNE.0000000000000191

Oermann, M. H. (2016). Supporting students with disabilities. Nurse Educator, 41(1), 1. https://doi.org/10.1097/NNE.0000000000000231

Pace, K. (2016). Inclusive approaches. Nursing Standard, 30(51), 35. https://doi.org/10.7748/ns.30.51.35.s38

Rankin, E. R., Nayda, R., Cocks, S., \& Smith, M. (2010). Students with disabilities and clinical placement: Understanding the perspective of healthcare organisations. International Journal of Inclusive Education, 14(5), 533542. https://doi.org/10.1080/13603110902730176

Ridley, C. (2011). The experiences of nursing students with dyslexia. Nursing Standard, 25(24), 35-42. https://doi.org/10.7748/ns.25.24.35.s50

Rosseter, R. (2018). Enhancing Diversity in the Nursing Workeforce Fact Sheet. Washington, DC: American Association of Colleges of Nursing.

Russell, C.L. (2005). An overview of the integrative research review. Progress in Transplantation, 15, 8-13. https://doi.org/10.1177/152692480501500102

Ryan, J. (2011). Access and participation in higher education of students with disabilities: Access to what? Australian Educational Researcher, 38(1), 73-93. https://doi.org/10.1007/s13384-010-0002-8

Salkeld, J. (2016). A model to support nursing students with dyslexia. Nursing Standard, 30(47), 46-51. https://doi.org/10.7748/ns.2016.e10266

Sanderson-Mann, J., J Wharrad, H., \& McCandless, F. (2012). An empirical exploration of the impact of dyslexia on placement-based learning, and a comparison with non-dyslexic students. Diversity \& Equality in Health \& Care, 9(2), 89-99. Retrieved from http://diversityhealthcare.imedpub.com

Sharples, N. (2013). An exploration of deaf women's access to mental health nurse education in the United Kingdom. Nurse Education Today, 33(9), 976-980. https://doi.org/10.1016/j.nedt.2012.10.017

Shpigelman, C., Zlotnick, C., \& Brand, R. (2016). Attitudes toward nursing students with disabilities: Promoting social inclusion. Journal of Nursing Education, 55(8), 441-449. https:/ /doi.org/10.3928/01484834-20160715-04

Sin, C. H. (2009). Medicalising disability? regulation and practice around fitness assessment of disabled students and professionals in nursing, social work and teaching professions in great britain. Disability and Rehabilitation, 31(18), 1520-1528. https://doi.org/10.1080/09638280903031572

Sin, C. H., \& Fong, J. (2008). 'Do no harm'? professional regulation of disabled nursing students and nurses in great Britain. Journal of Advanced Nursing, 62(6), 642-652. https://doi.org/10.1111/j.1365-2648.2008.04633.x

Symes, J. (2014). Nursing students with disabilities in the clinical setting: Nursing education leaders' perceptions of accommodations. (109763228). Retrieved from http://www.nursinglibrary.org/vhl/handle/10755/602932

Tee, S. R., Owens, K., Plowright, S., Ramnath, P., Rourke, S., James, C., \& Bayliss, J. (2010). Being reasonable: Supporting disabled nursing students in practice. Nurse Education in Practice, 10(4), $216-221$. https://doi.org/10.1016/j.nepr.2009.11.006 
Tee, S., \& Cowen, M. (2012). Supporting students with disabilities--promoting understanding amongst mentors in practice. Nurse Education in Practice, 12(1), 6-10. https://doi.org/10.1016/j.nepr.2011.03.020

United States Department of Education (2016) in 2011-2012, U.S. Department of Education, National Center for Education Statistics. (2016). Digest of Education Statistics, 2014 (2016-006), Chapter 3.

Author correspondence may be addressed to:

Leslie Neal-Boylan, PhD, APRN, CRRN, FAAN

$361^{\text {st }}$ Avenue

Charlestown Navy Yard

Boston, MA 02129

Lneal-boylan@mghihp.edu 